\title{
Impact of weight reduction on insulin resistance, adhesive molecules and adipokines dysregulation among obese type 2 diabetic patients
}

\author{
Shehab M Abd El-Kader', Osama H Al-Jiffri ${ }^{2}$
}

1. Departmentof Physical Therapy, Faculty of Applied Medical Sciences, King Abdulaziz University, Jeddah, Saudi Arabia.

2. Department of Medical Laboratory Technology, Faculty of Applied Medical Sciences, King Abdulaziz University, Jeddah, Saudi Arabia.

\begin{abstract}
Background: Type 2 diabetes mellitus is usually related to vascular problems and is associated with impairment in endothelial function characterized by impaired endothelial-dependent vasodilation and increased platelet adhesion. There is limitation in clinical studies that have addressed the beneficial effects of weight reduction in modulating biomarkers of endothelial dysfunction and adipokines dysregulation for obesity associated with type 2 diabetes mellitus.

Objective: This study was designed to detect the effects of weight loss on insulin resistance, adhesive molecules and adipokines dysregulation in obese type 2 diabetic patients.

Methods: Eighty obese patients with type 2 diabetes mellitus, their age ranged from 35-55 years and their body mass index ranged from $31-37 \mathrm{~kg} / \mathrm{m}^{2}$ were equally assigned into 2 groups: the weight reduction group received aerobic exercises in addition to diet regimen, where the control group received medical treatment only for 12 weeks.

Results: There was a 24.04\%, 19.33\%, 22.78\%,12.28\%, 9.35\%, 22.53\% \& $10.12 \%$ reduction in mean values of Homeostasis Model Assessment-Insulin Resistance Index (HOMA-IR), Leptin, Adiponectin, Resistin, intercellular cell adhesion molecule -1 (ICAM-1), vascular cell adhesion molecule-1 (VCAM-1) and E-selectin \& body mass index (BMI) respectively in addition to $26.20 \% \& 24.58 \%$ increase in the mean values of adiponectin \& the quantitative insulin-sensitivity check index (QUICKI) respectively in group (A) at the end of the study. The mean values of leptin, resistin, insulin, HOMA-IR, ICAM-1, VCAM-1, E-selectin \& BMI were significantly decreased in addition to significant increase in the mean values of adiponectin \& QUICKI in group (A) those that received aerobic exercise training in addition to diet regimen. While the results of group (B) those that received no treatment intervention were not significant. In addition, there were significant differences between mean levels of the investigated parameters in group (A) and group (B) after treatment $(\mathrm{P}<0.05)$.

Conclusion: Within the limit of this study, $10 \%$ reduction in body mass index modulates insulin resistance, adhesive molecules and adipokines dysregulation among obese type 2 diabetic patients.
\end{abstract}

Keywords: Type 2 Diabetes, obesity, adhesive molecules, adipokines, insulin resistance, weight reduction.

DOI: https://dx.doi.org/10.4314/ahs.v18i4.5

Cite as: Abd El-Kader SM, Al-Jiffri OH. Impact of weight reduction on insulin resistance, adhesive molecules and adipokines dysregulation among obese type 2 diabetic patients. Afri Health Sci. 2018;18(4): 873-883. https://dx.doi.org/10.4314/ahs.v18i4.5

\section{Corresponding author:}

Shehab M Abd El-Kader,

Department of Physical Therapy,

Faculty of Applied Medical Sciences,

King Abdulaziz University,

P.O. Box 80324, Jeddah, 21589, Saudi Arabia.

Email: salmuzain@kau.edu.sa

\section{Introduction}

Type 2 diabetes (T2DM) is an important cardiovascular $(\mathrm{CV})$ risk factor ${ }^{1}$. Obesity represents a state of increase in adipose tissue mass due to the increase in the number and size of adipocytes ${ }^{2}$. Diabetes increases cardiovascular risk and reduces life expectancy, with most of excess mortality being attributable to cardiovascular causes ${ }^{3}$. In addition, T2DM is typically associated with reduced high density lipoprotein cholesterol (HDL-C) and impaired HDL-C 
function ${ }^{4,5}$. The hypertension that typically accompanies T2DM seems to be the most significant contributor to this increased risk 6 .

Adipose tissue is recognized as an active endocrine organ, which secretes adipocytokines involved in the local and systemic regulation of numerous metabolic and inflammatory processes ${ }^{7}$. Dysregulated endocrine function of the adipose tissue contributes to the development of obesity related metabolic disorders including insulin resistance, T2DM and atherosclerosis ${ }^{8}$.

Adiponectin is an adipokine with insulin sensitizing and anti-inflammatory activities. Adiponectin and insulin resistance is an important link between visceral adiposity and atherosclerosis. Adiponectin improves systemic glucose tolerance and protects the vasculature from atherosclerosis ${ }^{9}$. Adiponectin exerts both vasodilatory and insulin-sensitizing actions and its levels are decreased in insulin-resistant humans and animals ${ }^{10}$. Circulating levels of adiponectin decrease both in obesity and in patients with T2DM. There is a close association between inflammatory markers, insulin resistance and incidence of $\mathrm{T}_{2} \mathrm{DM}^{11}$. Additionally, hypoadiponectinemia is an independent risk factor for developing T2DM and cardiovascular disease ${ }^{12}$.

Type 2 diabetic patients have abnormal levels of inflammatory markers, which lead to endothelial cell dysfunction $^{13}$, which may be induced by hyperlipidemia, hyperinsulinemia and pancreatic $\beta$-cell failure ${ }^{14}$. Insulin has an essential role in regulation of vascular function by stimulation of the expression of vascular cell adhesion molecule (vascular cell adhesion molecule-1 (VCAM1), intercellular cell adhesion molecule -1 (ICAM-1) and E-selectin on endothelium, that is why endothelial dysfunction is associated with insulin resistance ${ }^{15}$. Endothelial dysfunction is characterized by prothrombic properties,pro-inflammatory state and reduced vasodilation ${ }^{16,17}$. Endothelial function is a marker of overall cardiovascular health and a predictor of future cardiovascular events ${ }^{18}$. Aerobic exercises associated with appropriate diet regimen were reported to protect against atherosclerosis in non-insulin dependent diabetes mellitus ${ }^{19}$. However, weight reduction program modulates markers of systemic inflammation, endothelial function and adipokines that are usually associated with better cardiovascular system prognosis in obese subjects ${ }^{20,21}$.

As there is inconclusive data regarding the impact of weight reduction upon the adipokines and adhesive molecules dysregulation in obese type 2 diabetic patients, therefore, the study aimed to determine the impact of 12 weeks of weight reduction program on insulin resistance, adipokines and adhesive molecules dysregulation in obese type 2 diabetic patients.

\section{Patients and methods \\ Subjects}

Eighty obese T2DM patients (48 males and 32 females) with body mass index (BMI) ranged from 30 to $34 \mathrm{Kg} /$ $\mathrm{m}^{2}$, treated with oral hypoglycemic agents e.g. metformin and/or pioglitazone were selected for the study on referral to Internal Medicine Department, King Abdulaziz University Teaching Hospital, Saudi Arabia. They were checked for fasting/random glucose levels. Only participants who had fasting blood sugar levels more than $5.6 \mathrm{mmol} / 1$ or random blood sugar level more than 7.8 $\mathrm{mmol} / \mathrm{l}$ (impaired blood sugar) were included in this study and were further checked for type 2 diabetes mellitus as per recent American Diabetes Association criteria i.e. fasting blood sugar $\geq 7.0 \mathrm{mmol} / 1$ or post-prandial blood sugar $\geq 11.1 \mathrm{mmol} / 1$ 2-h plasma glucose $11.1 \mathrm{mmol} / 1$ during an oral glucose tolerance test and glycosylated hemoglobin $(\mathrm{HbA} 1 \mathrm{c} \%)>6.5 \%{ }^{22}$. Exclusion criteria included smokers, kidney insufficiency, congestive heart failure, pregnant female patients, hepatitis and respiratory failure. Detailed clinical history was obtained and p included the age, sex, symptoms suggestive of diabetes and family history of diabetes. Physical examinations included anthropometric measurements such as height, weight, BMI and waist circumference.

Participants were included two groups; group (A) received treadmill aerobic exercise training on treadmill in addition to diet regimen. However, group (B) received no exercise training. The CONSORT diagram outlining the details of the screening, run-in and randomization phases of the study and reasons for participant exclusion can be found in figure (1). Informed consent was obtained from all participants. This study was approved by the Scientific Research Ethical Committee, Faculty of Applied Medical Sciences at King Abdulaziz University. 


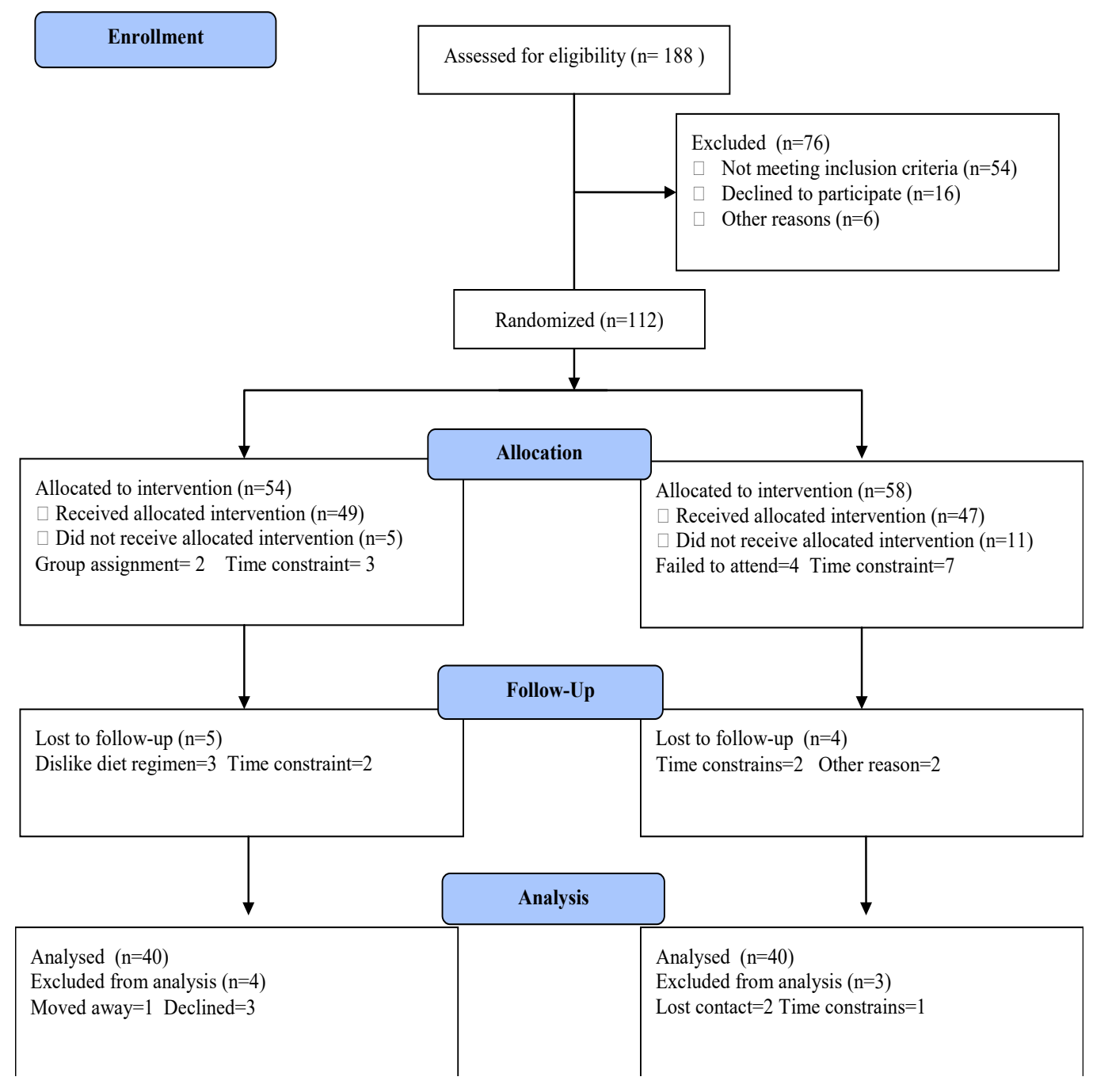

Figure 1

\section{Measurements}

All laboratory examinations were performed at Laboratory of King Abdalaziz University Teaching Hospitals.

A. Measurement of adiopkines and insulin resistance: After a 10 hours overnight fast, venous blood samples were drawn to determine levels of leptin, adiponectin and resistin. Serum level of leptin was measured with DRG leptin ELISA Catalog number EIA-2395, supplied by DRG instruments $\mathrm{GmbH}$, Germany and serum level of adiponectin was determined using AviBion human adiponectin (Acrp 30) ELISA kit ref. no. ADIPO 25 (Orgenium Laboratories, Finland), while serum level of resistin was measured by ELISA using commercially available kits (resistin Rapidbio, West Hills, CA, USA; CK-18: PEVIVA, Alexis, Grunwald, Germany) according to the manufacturer's instructions. Human insulin was measured with an insulin kit (Roche Diagnostics, Indianapolis, IN, USA) using a cobas immunoassay analyzer(Roche Diagnostics). Insu- lin resistance was assessed by homeostasis model assessment (HOMA-IR). HOMA-IR = fasting blood glucose

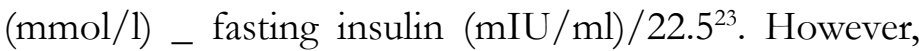
insulin sensitivity was assessed by The quantitative insulin-sensitivity check index (QUICKI) using the formula: QUICKI=1/log(insulin $)+\log (\text { glucose })^{24}$. All serum samples were analyzed in duplicates.

B. Measurement of adhesive molecules biomarkers: Biomarkers of adhesive molecules which included adhesion molecules (ICAM-1 and VCAM-1) and soluble E-selectin levels were measured from frozen plasma samples stored at $-80{ }^{\circ} \mathrm{C}$. Enzyme-linked immunosorbent assays kits (ELISAs) were used to measure soluble levels of ICAM1, VCAM-1 and sE-selectin (GE Healthcare Amersham, Biotrak Easy ELISA), which employs the quantitative sandwich enzyme immunoassay technique.

C. Measurement of anthropometric parameters: Body weight 
of all participants was measured with (HC4211, Cas Korea, South Korea) while wearing hospital gowns and undergarments. Where the height was measured with a digital stadiometer (JENIX DS 102, Dongsang), so Body Mass Index (BMI) was computed as BMI= Body weight/ Height ${ }^{2}$.

\section{Procedures}

All participants were divided randomly into the following groups:

1. Group (A): Forty obese type 2 diabetic patients were submitted to the aerobic exercise training to complete a 12-week aerobic exercise on a treadmill which was conducted according to recommendation of American College of Sports Medicine regarding aerobic exercise application ${ }^{25}$.Training program included 5 minutes for warming -up in the form of range motion and stretching exercises, 30 minutes of aerobic exercise training ( 60$70 \%$ of maximum heart rate) and 10 minutes of cooling down ( on treadmill with low speed and without inclination). Participants had 3 sessions / week for 3 months with close supervision of physical therapist. In addition, a dietician performed an interview-based food survey for all participants of group (A) for detection of feeding habits, abnormal dietary behavior and to prescribe the balanced low caloric diet that provides 1200 Kilocalories / day for 12 weeks.

2. Group (B): Forty obese type 2 diabetic patients of both sexes maintained their ordinary life style and received no exercise training.

\section{Statistical analysis}

The mean values of the investigated parameters obtained before and after three months in both groups were compared using paired " $t$ " test. Independent " $t$ " test was used for the comparison between the two groups $(\mathrm{P}<0.05)$.

\section{Results}

Eighty obese patients with type 2 diabetes mellitus completed the screening evaluation. The baseline characteristics of the participants are shown in table (1). Most participants $(60 \%)$ were men. Forty participants were assigned group (A) ( $\mathrm{n}=40 ; 23$ males and 16 females) and group (B) ( $n=40,25$ males and 15 females). None of the baseline characteristics differed significantly between the two groups as listed in table (1).

Table (1): Mean value of baseline characteristics of subjects for participants in both groups

\begin{tabular}{|l|c|c|c|}
\hline & Group (A) & Group (B) & Significance \\
\hline Age (year) & $48.73 \pm 6.26$ & $50.12 \pm 5.91$ & $\mathrm{P}>0.05$ \\
\hline Gender (male/female) & $23 / 17$ & $25 / 15$ & $\mathrm{P}>0.05$ \\
\hline BMI $\left(\mathrm{kg} / \mathrm{m}^{2}\right)$ & $32.51 \pm 3.87$ & $33.14 \pm 3.22$ & $\mathrm{P}>0.05$ \\
\hline Duration of diabetes(years) & $12.23 \pm 4.64$ & $11.52 \pm 4.58$ & $\mathrm{P}>0.05$ \\
\hline Waist circumference (cm) & $103.42 \pm 8.36$ & $101.47 \pm 7.93$ & $\mathrm{P}>0.05$ \\
\hline Waist-hip ratio & $0.97 \pm 0.08$ & $0.93 \pm 0.07$ & $\mathrm{P}>0.05$ \\
\hline Body fat $(\%)$ & $36.4 \pm 7.61$ & $35.88 \pm 6.95$ & $\mathrm{P}>0.05$ \\
\hline SBP $(\mathrm{mmHg})$ & & & $\mathrm{P}>0.05$ \\
\hline DBP $(\mathrm{mmHg})$ & $143.57 \pm 10.31$ & $145.41 \pm 9.86$ & $\mathrm{P}>0.05$ \\
\hline Total Cholesterol $(\mathrm{mg} / \mathrm{dL})$ & $87.44 \pm 7.15$ & $88.69 \pm 8.21$ & $\mathrm{P}>0.05$ \\
\hline HDL-C( mg/dL) & $199.72 \pm 21.63$ & $196.94 \pm 19.54$ & $\mathrm{P}>0.05$ \\
\hline Triglycerides( mg/dL) & $43.81 \pm 8.45$ & $46.17 \pm 9.38$ & $\mathrm{P}>0.05$ \\
\hline HBA1c $(\%)$ & $145.64 \pm 13.87$ & $142.33 \pm 14.56$ & $\mathrm{P}>0.05$ \\
\hline Glucose (mmol/L) & $9.17 \pm 2.53$ & $8.92 \pm 2.65$ & $\mathrm{P}>0.05$ \\
\hline Insulin (pmol/L) & $5.32 \pm 1.13$ & $5.18 \pm 1.08$ & $\mathrm{P}>0.05$ \\
\hline
\end{tabular}

BMI: Body Mass Index; SBP: Systolic blood pressure; DBP: Diastolic blood pressure;

HDL-C: High-density lipoprotein cholesterol; HBA1c: glycosylated hemoglobin. 
There was a $24.04 \%, 19.33 \%, 22.78 \%, 12.28 \%, 9.35 \%$, $22.53 \%$ \& $10.12 \%$ reduction in mean values of $\mathrm{HO}$ MA-IR, Leptin, Adiponectin, Resistin, ICAM-1, VCAM1 and E-selectin \& BMI respectively in addition to $26.20 \%$ $\& 24.58 \%$ increase in the mean values of adiponectin \& QUICKI respectively in group (A) at the end of the study. The mean values of leptin, resistin, insulin, HOMA-IR, ICAM-1, VCAM-1, E-selectin \& BMI were significantly decreased in addition to significant increase in the mean values of adiponectin \& QUICKI in group (A) those that received aerobic exercise training in addition to diet regimen. While the results of group (B) who received no treatment intervention were not significant. Also, there were significant differences between mean levels of the investigated parameters in group (A) and group (B) after treatment (Table 2, 3, \& 4) $(\mathrm{P}<0.05)$.

Table (2): Mean value and significance of BMI, QUICKI, HOMA-IR, Leptin, Adiponectin, Resistin, ICAM-1, VCAM-1 and E-selectin in group (A) before and after treatment.

\begin{tabular}{|l|c|c|c|c|}
\hline \multirow{2}{*}{} & \multicolumn{2}{|c|}{ Mean +SD } & \multirow{2}{*}{ T-value } & \multirow{2}{*}{ Significance } \\
\cline { 2 - 3 } & Pre & Post & & \\
\hline BMI $\left(\mathrm{kg} / \mathrm{m}^{2}\right)$ & $32.51 \pm 3.87^{*}$ & $29.22 \pm 3.74$ & 6.73 & $\mathrm{P}<0.05$ \\
\hline QUICKI & $0.118 \pm 0.019^{*}$ & $0.147 \pm 0.015$ & 5.12 & $\mathrm{P}<0.05$ \\
\hline HOMA-IR & $5.24 \pm 1.57^{*}$ & $3.98 \pm 1.31$ & 4.67 & $\mathrm{P}<0.05$ \\
\hline Leptin $(\mathrm{Ng} / \mathrm{ml})$ & $30.21 \pm 4.32^{*}$ & $24.37 \pm 3.91$ & 6.32 & $\mathrm{P}<0.05$ \\
\hline Adiponectin $(\mu \mathrm{g} / \mathrm{mL})$ & $10.42 \pm 2.65^{*}$ & $13.15 \pm 2.48$ & 5.74 & $\mathrm{P}<0.05$ \\
\hline Resistin $(\mathrm{ng} / \mathrm{mL})$ & $15.23 \pm 2.87^{*}$ & $11.76 \pm 2.22$ & 6.21 & $\mathrm{P}<0.05$ \\
\hline ICAM-1 $(\mathrm{ng} / \mathrm{ml})$ & $92.71 \pm 9.36^{*}$ & $81.32 \pm 8.17$ & 7.56 & $\mathrm{P}<0.05$ \\
\hline VCAM-1 $(\mathrm{ng} / \mathrm{ml})$ & $816.58 \pm 28.15^{*}$ & $740.26 \pm 21.83$ & 9.81 & $\mathrm{P}<0.05$ \\
\hline E-selectin $(\mathrm{ng} / \mathrm{ml})$ & $15.93 \pm 2.76^{*}$ & $12.34 \pm 2.54$ & 7.56 & $\mathrm{P}<0.05$ \\
\hline
\end{tabular}

BMI: Body Mass Index; QUICKI: The quantitative insulin-sensitivity check index; HOMA-IR: Homeostasis Model Assessment-Insulin Resistance Index; ICAM-1: Inter-Cellular Adhesion Molecule; VCAM-1: Vascular Cell Adhesion Molecule; $\left.{ }^{*}\right)$ indicates a significant difference, $\mathrm{P}<0.05$.

Table (3): Mean value and significance of BMI, QUICKI, HOMA-IR, Leptin, Adiponectin, Resistin, ICAM-1, VCAM-1 and E-selectin in group (B) before and after treatment.

\begin{tabular}{|l|c|c|c|c|}
\hline \multirow{2}{*}{} & \multicolumn{2}{|c|}{ Mean +SD } & \multirow{2}{*}{ T-value } & \multirow{2}{*}{ Significance } \\
\cline { 2 - 3 } & Pre & Post & & \\
\hline BMI $\left(\mathrm{kg} / \mathrm{m}^{2}\right)$ & $33.14 \pm 3.22$ & $33.85 \pm 3.23$ & 1.19 & $\mathrm{P}>0.05$ \\
\hline QUICKI & $0.121 \pm 0.024$ & $0.115 \pm 0.018$ & 0.87 & $\mathrm{P}>0.05$ \\
\hline HOMA-IR & $5.63 \pm 2.13$ & $5.97 \pm 2.24$ & 1.26 & $\mathrm{P}>0.05$ \\
\hline Leptin $(\mathrm{Ng} / \mathrm{ml})$ & $31.36 \pm 4.16$ & $31.68 \pm 4.51$ & 1.40 & $\mathrm{P}>0.05$ \\
\hline Adiponectin $(\mu \mathrm{g} / \mathrm{mL})$ & $10.15 \pm 2.32$ & $9.87 \pm 2.17$ & 0.86 & $\mathrm{P}<0.05$ \\
\hline Resistin $(\mathrm{ng} / \mathrm{mL})$ & $16.11 \pm 2.53$ & $16.34 \pm 2.18$ & 1.21 & $\mathrm{P}>0.05$ \\
\hline ICAM-1 $(\mathrm{ng} / \mathrm{ml})$ & $93.19 \pm 10.22$ & $94.50 \pm 9.83$ & 1.58 & $\mathrm{P}>0.05$ \\
\hline VCAM-1 $(\mathrm{ng} / \mathrm{ml})$ & $820.21 \pm 26.75$ & $826.10 \pm 29.21$ & 1.89 & $\mathrm{P}>0.05$ \\
\hline E-selectin $(\mathrm{ng} / \mathrm{ml})$ & $16.14 \pm 2.50$ & $16.62 \pm 2.65$ & 0.84 & $\mathrm{P}>0.05$ \\
\hline
\end{tabular}

BMI: Body Mass Index; QUICKI: The quantitative insulin-sensitivity check index; HOMA-IR: Homeostasis Model Assessment-Insulin Resistance Index; ICAM-1: Inter-Cellular Adhesion Molecule; VCAM-1: Vascular Cell Adhesion Molecule. 
Table (4): Mean value and significance of BMI, QUICKI, HOMA-IR, Leptin, Adiponectin, Resistin, ICAM-1, VCAM-1 and E-selectin in group (A) and group (B) at the end of the study.

\begin{tabular}{|l|c|c|c|c|}
\hline \multirow{2}{*}{} & \multicolumn{2}{|c|}{ Mean +SD } & \multirow{2}{*}{ T-value } & \multirow{2}{*}{ Significance } \\
\cline { 2 - 3 } & Group (A) & Group (B) & & \\
\hline BMI $\left(\mathrm{kg} / \mathrm{m}^{2}\right)$ & $29.22 \pm 3.74^{*}$ & $33.85 \pm 3.23$ & 5.23 & $\mathrm{P}<0.05$ \\
\hline QUICKI & $0.147 \pm 0.015^{*}$ & $0.115 \pm 0.018$ & 4.10 & $\mathrm{P}<0.05$ \\
\hline HOMA-IR & $3.98 \pm 1.31^{*}$ & $5.97 \pm 2.24$ & 3.83 & $\mathrm{P}<0.05$ \\
\hline Leptin $(\mathrm{Ng} / \mathrm{ml})$ & $24.37 \pm 3.91^{*}$ & $31.68 \pm 4.51$ & 5.14 & $\mathrm{P}<0.05$ \\
\hline Adiponectin $(\mu \mathrm{g} / \mathrm{mL})$ & $13.15 \pm 2.48^{*}$ & $9.87 \pm 2.17$ & 4.32 & $\mathrm{P}<0.05$ \\
\hline Resistin $(\mathrm{ng} / \mathrm{mL})$ & $11.76 \pm 2.22^{*}$ & $16.34 \pm 2.18$ & 5.12 & $\mathrm{P}<0.05$ \\
\hline ICAM-1 $(\mathrm{ng} / \mathrm{ml})$ & $81.32 \pm 8.17^{*}$ & $94.50 \pm 9.83$ & 6.43 & $\mathrm{P}<0.05$ \\
\hline VCAM-1 $(\mathrm{ng} / \mathrm{ml})$ & $740.26 \pm 21.83^{*}$ & $826.10 \pm 29.21$ & 8.26 & $\mathrm{P}<0.05$ \\
\hline E-selectin$(\mathrm{ng} / \mathrm{ml})$ & $12.34 \pm 2.54^{*}$ & $16.62 \pm 2.65$ & 6.27 & $\mathrm{P}<0.05$ \\
\hline
\end{tabular}

BMI: Body Mass Index; QUICKI : The quantitative insulin-sensitivity check index; HOMA-IR:

Homeostasis Model Assessment-Insulin Resistance Index; ICAM-1: Inter-Cellular Adhesion Molecule; VCAM-1:Vascular Cell Adhesion Molecule; $(*)$ indicates a significant difference, $\mathrm{P}<0.05$.

\section{Discussion}

Type 2 diabetes mellitus is characterized by hyperglycemia due to insulin resistance, which over time leads to a myriad of micro- and macrovascular complications. Individuals with T2DM are at a much higher risk (two to four times that of the background population) of developing coronary artery disease ${ }^{26}$, peripheral vascular disease ${ }^{27}$, and cerebrovascular disease $\mathrm{e}^{28}$. Mortality from cardiovascular disease may be up to four times higher in patients with T2DM ${ }^{29}$. However, adiponectin is a circulating adipose tissue-derived hormone that is down regulated in obese individuals ${ }^{30}$. Experimental studies show that adiponectin plays a protective role in the development of insulin resistance, atherosclerosis, and inflammation ${ }^{31}$. Insulin resistance and its manifestations predict and precede T2DM and its cardiovascular complications ${ }^{32}$. Insulin resistance characterizing obese subjects has also been shown to be associated with endothelial dysfunction ${ }^{33,34}$. The optimal management of obesity starts with a combination of diet, physical activity, and behavioral modification. Previous studies demonstrated beneficial effects of exercise training and caloric restrictions on pro-inflammatory state associated with endothelial dysfunction after weight loss ${ }^{35-37}$.

The main finding of the present study was that weight reducing program ameliorate insulin resistance, adhesive molecules (ICAM-1 VCAM-1 and E-selectin) as well as improvement in adipokines dysregulation (Adiponectin, Leptin and Resistin) in obese type 2 diabetic patients as a result of weight loss, these results are in line with many previous studies.

Regarding insulin resistance, this study proved that life style modification (aerobic exercise and diet regimen) significantly improved insulin resistance because of weight reduction. These results agreed with Angelico et al. who proved that $5 \%-10 \%$ weight loss as a result of diet regimen modulates insulin resistance in patients with metabolic syndrome ${ }^{38}$, also Bacchi et al. conducted a randomized controlled trial of 31 sedentary adults with type 2 diabetes and non-alcoholic fatty liver comparing the effects of 4 months of aerobic and resistance training on insulin sensitivity and hepatic steatosis. Hepatic fat content, hepatic steatosis and insulin sensitivity were reduced in both intervention groups ${ }^{39}$. Several mechanisms have been proposed to be responsible for the increases in insulin sensitivity after exercise training. These include increased post-receptor insulin signaling, increased glucose transporter protein and mRNA, increased activity of glycogen syntheses and hexokinase, decreased release and increased clearance of free fatty acids, increased muscle glucose delivery and changes in muscle composition ${ }^{40}$.

Concerning adhesive molecules, this study proved that life style modification (aerobic exercise and diet reg- 
imen) significantly improved ICAM-1, VCAM-1 and E-selectin because of weight reduction. These results agreed with previous studies conducted in obese populations that have shown reductions in VCAM- $1^{41}$ and ICAM-1 ${ }^{42-44}$ following weight loss. Sharman and Volek conducted a 6 -week crossover dietary intervention with reduced energy diets (low fat vs very low carbohydrate $\sim 1500 \mathrm{kcal}$ ) in 15 overweight men, resulted in reduction in plasma ICAM- $1^{45}$. Forsythe et al. conducted a parallel study with longer period dietary intervention (12-week) in a group of overweight individuals with dyslipidemia and stated that weight reduction was achieved which led to reduction in E-selectin and $\mathrm{ICAM}^{46}$. Thomson et al. conducted a study on 50 overweight/obese women with polycystic ovary syndrome to determine if 20 weeks of a high-protein energy-restricted diet with or without exercise in women with polycystic ovary syndrome could improve endothelial function. Participants were randomly assigned by computer generation to one of three 20 -week interventions: diet only $(6000 \mathrm{~kJ} / \mathrm{day})$, diet and aerobic exercise $(6000 \mathrm{~kJ} /$ day and 5 walking sessions/week) and diet and combined aerobic-resistance exercise (6000 kJ/ day, three walking and two-strength sessions/week). All three treatments resulted in significant weight loss, also VCAM-1 and ICAM-1 levels decreased with weight loss with no differences between treatments ${ }^{47}$.

Garanty-Bogacka et al. applied a study on fifty six obese adolescents, participating in an obesity intervention program, were studied before and after 1 year program consisting of moderate physical activity (exercise group including 37 participants) or hypocaloric diet (diet group: 19 subjects) and concluded that moderate-intensity training alone reduced cell adhesion (VCAM-1 and ICAM-1) in obese adolescents more than observed after caloric restriction ${ }^{48}$. The mechanisms of adhesive molecules improvement are not clearly elucidated, but some studies suggest that reduction in circulating level of markers of endothelial activation and oxidative stress ${ }^{49,50}$ as well as increases in nitrous oxide bioavailability through repetitive increase of shear stress may serve as mechanisms ${ }^{51,52}$.

Regarding adipokines levels, this study proved that life style modification (aerobic exercise and diet regimen) significantly modulated adipokines (Adiponectin, Leptin and Resistin) because of weight reduction. These results agreed with Lang et al. investigated the effects of an 8-week weight-control program on serum adiponec- tin and blood lipid level profiles in 3 obese men and 11 obese women, their findings suggest that weight reduction has anti-inflammatory and anti-atherogenic effects via increased serum adiponectin levels ${ }^{53}$. Esposito et al. reported that lifestyle modification by obese subjects for a period of 2 years led to decreased body weight and C-reactive protein but increased adiponectin levels ${ }^{54}$ as adiponectin secretion may be inhibited by obesity through a feedback loop ${ }^{55}$. Rokling-Andersen et al. examined the separate and combined effects of a one year exercise and diet intervention on several adipokines and concluded that beyond the effects on body fatness, diet or exercise intervention alone or in combination mainly had effects on adiponectin and tumor necrosis factor- alpha (TNF- $\alpha)$ concentrations ${ }^{56}$. In addition, previous studies demonstrated that long-term weight loss after bariatric surgery is accompanied by a decreased pro-inflammatory state and increased the circulating level of adiponectin ${ }^{57-61}$. Jung et al. proved that long-term exercise program and a diet led obese individuals to reduce significantly the level of resistin and leptin ${ }^{62}$. Jones et al. have studied the effect of 8 -week aerobic exercise on lipid levels of serum, leptin, adiponectin, and resistin in overweight adolescents and reported a significant decrease of resistin ${ }^{63}$. Kadoglou et al. studied the effect of 16-week regular aerobic exercises with a maximal oxygen consumption $\left(\mathrm{VO}_{2} \max \right)$ of 50 to 85 percent on resistin level in patients with type 2 diabetic and overweight ones. They reported a significant decrease in resistin level among the participants ${ }^{64}$. In the study by Elloumi et al. two months of exercise with weight loss, led to a significant decrease in resistin level among obese adolescents ${ }^{65}$. Balducci et al. reported that 12 months of regular physical activity could decrease the level of resistin in patients with diabetes and obesity ${ }^{66}$.

The current study has important strengths and limitations. The major strength is the supervised nature of the study. Supervising physical activity and diet regimen remove the need to question compliance or to rely on activity questionnaires. Further, all exercise sessions were supervised and adherence to the activities was essentially 100\%. In addition, our study had a large number of subjects enrolled/involved, leading to excellent statistical power to detect exercise exposure effects across groups. Moreover, the study was randomized; hence, we can extrapolate adherence to the general population. On the other hand, the major limitations is that this study did not include 
some biomarkers that could be modulated with weight reduction among patients with T2DM. Finally, within the limit of this study, $10 \%$ reduction in body mass index modulates insulin resistance, adhesive molecules and adipokines dysregulation among obese type 2 diabetic patients. Further researches are needed to explore the impact of different exercise training techniques on quality of life and other biochemical parameters among patients with type 2 diabetes mellitus.

\section{Acknowledgment}

This project was funded by the Deanship of Scientific Research (DSR) at King Abdulaziz University, Jeddah, under grant no. (G-10-142-38). The authors, therefore, acknowledge with thanks DSR for technical and financial support.

\section{Conflict of interest}

None.

\section{References}

1. Leiter LA, Fitchett DH, Gilbert RE, et al. Identification and management of cardiometabolic risk in Canada: a position paper by the cardiometabolic risk working group (executive summary). Can J Cardiol. 2011;27:124-31 PubMed .

2. DeFronzo RA. Insulin resistance, lipotoxicity, type 2 diabetes and atherosclerosis: the missing links. The Claude Bernard Lecture 2009. Diabetologia. 2010;53(7): 1270-87. PubMed.

3. Seshasai SR, Kaptoge S, Thompson A, et al. Diabetes mellitus, fasting glucose, and risk of cause-specific death. N Engl J Med. 2011;364:829e41.

4. Besler C, Luscher TF, Landmesser U. Molecular mechanisms of vascular effects of High-density lipoprotein: alterations in cardiovascular disease. EMBO Mol Med. 2012;4:251e68.

5. Farbstein D, Levy AP. HDL dysfunction in diabetes: causes and possible treatments. Expert Rev Cardiovasc Ther. 2012;10:353e61.

6. Chen G, McAlister FA, Walker RL, Hemmelgarn BR, Campbell NRC. Cardiovascular outcomes in Framinghamparticipantswithdiabetes:the importance ofbloodpressure. Hypertension. 57:891-897; 2011.

7. Greenberg AS, Obin MS. Obesity and the role of adipose tissue in inflammation and metabolism. Am J Clin Nutr. 2006;83(2):461. S-5S Review. PubMed.
8. Murdolo G, Smith U. The dysregulated adipose tissue: a connecting link between insulin resistance, type 2 diabetes mellitus and atherosclerosis. Nutr Metab Cardiovasc Dis. 2006;16(Suppl 1):S35-8.

9. Li FY, Cheng KK, Lam KS, Vanhoutte PM, Xu A. Cross-talk between adipose tissue and vasculature: role of adiponectin. Acta Physiol (Oxf). 2010 Nov 10.

10. Zhao 1, Fu Z, Liu Z. Adiponectin and insulin cross talk: The microvascular connection. Tren Dsin Cardiovascular Medinine. 24 (2014)319 - 324.

11. Ndumele CE, Pradhan AD, Ridker PM. Interrelationships between inflammation, C-reactive protein, and insulin resistance. J Cardiometab Syndr. 2006;1(3):190-6. PubMed.

12. Misu H, Ishikura K, Kurita S, Takeshita Y, Ota T, Saito Y, Takahashi K, Kaneko S, Takamura T, 2012. Inverse correlation between serum levels of selenoprotein $\mathrm{P}$ and adiponectin in patients with type 2 diabetes. PLoS One. 7, e34952.

13. Gómez JM, Vila R, Catalina P, Soler J, Badimón L, Sahún M. (2008): The markers of inflammation and endothelial dysfunction in correlation with glycated haemoglobin are present in type 2 diabetes mellitus patients but not in their relatives. Glycoconj J; 25(6):573-9.

14. Ansar S, Koska J, Reaven PD. (2011): Postprandial hyperlipidemia, endothelial dysfunction and cardiovascular risk: focus on in cretins. Cardiovasc Diabetol; 7: 10:61.

15. Cersosimo E, DeFronzo RA.(2006):Insulin resistance and endothelial dysfunction: the road map to cardiovascular diseases. Diabetes Metab Res Rev; 22(6):423-36.

16. Endemann DH, Schiffrin EL. (2004): Endothelial dysfunction. J Am Soc Nephrol; 15(8):1983-92.

17. Gómez JM, Sahún M, Vila R, Domènech P, Catalina P, Soler J, Badimón L. (2007): Elevation of E-selectin concentrations may correlate with potential endothelial dysfunction in individuals with hypopituitarism during therapy with growth hormone. Curr Neurovasc Res; 4(1):55-62. 18. Widlansky ME, Gokce N, Keaney JF Jr, Vita JA. The clinical implications of endothelial function. $J$ Am Coll Cardiol. 2003; 42(7): 1149-1160. PubMed.

19. Fisher G, Hyatt TC, Hunter GR, Oster RA, Desmond RA, Gower BA. Effect of diet with and without exercise training on markers of inflammation and fat distribution in overweight women. Obesity (Silver Spring), 19 (2011), pp. 1131-1136

20. Brandt C, Pedersen BK.The role of exercise-induced myokines in muscle homeostasis and the defense against 
chronic diseases. J Biomed Biotechnol, 2010 (2010), p. 520258 21. Jorge ML, de Oliveira VN, Resende NM, Paraiso LF, Calixto A, Diniz AL. The effects of aerobic, resistance, and combined exercise on metabolic control, inflammatory markers, adipocytokines, and muscle insulin signaling in patients with type 2 diabetes mellitus. Metabolism, 60 (2011), pp. 1244-1252.

22. American Diabetes Association. Diagnosis and classification of diabetes mellitus. Diabetes Care. 2010;33(Suppl. 1):S62-9.

23. Matthews DR, Hosker JP, Rudenski AS, Naylor BA, Treacher DF, Turner RC. Homeostasis model assessment: insulin resistance and beta cell function from plasma FBS and insulin concentrations in man. Diabetologia. 1985;28:412-9. PubMed.

24. Katz A, Nambi SS, Mather K, Baron DA, Follman DA, Sullivan F, et al. Quantitative insulin sensitivity check index: a simple, accurate method for assessing insulin sensitivity in humans. J Clin Endocrinol Metab. 2000;85:24022410.

25. American College of Sports Medicine .Guidelines for graded exercise testing and exercise prescription, Lea \& Febiger, Philadelphia, 2005.

26. Haffner SM, Lehto S, Ronnemaa T, Pyoral a K, Laakso M. Mortality from coronary heart disease in subjects with type 2 diabetes and in nondiabetic subjects with and without prior myocardial infarction. N. Engl. J. Med. 339:229-234; 1998.

27. Newman A, Siscovick D, Manolio T, Polak J, Fried L, Borhani N, Wolfson S. Ankle-arm index as a marker of atherosclerosis in the Cardiovascular Health Study. Cardiovascular Heart Study(CHS) Collaborative Research Group. Circulation. 88:837-845; 1993.

28. Wannamethee SG, Perry IJ, Shaper AG. Non fasting serum glucose and insulin concentrations and the risk of stroke. Stroke. 30:1780-1786; 1999.

29. Almdal T, Scharling H, Jensen JS, Vestergaard H. The independent effect of type 2 diabetes mellitus on ischemic heart disease ,stroke, and death: a population-based study of 13000 men and women with 20 years of followup. Arch. Intern. Med. 164:1422-1426; 2004.

30. Kim DH, Vanella L, Inoue K, et al. Epoxyeicosatrienoic acid agonist regulates human mesenchymal stem cell-derived adipocytes through activation of HO-1-pAKT signaling and a decrease in PPARgamma. Stem Cells Dev. 2010;19:1863-73 PubMed.

31. Shibata R, Sato K, Pimentel DR, et al. Adiponectin protects against myocardial ischemia-reperfusion injury through AMPK- and COX-2-dependent mechanisms. Nat Med. 2005;11:1096-103 PubMed.

32. Yki-Ja rvinen H. Prediction and prevention of non-insulin-dependent diabetes mellitus. In Williams $G$ \& Pickup J (eds) Textbook of Diabetes. Oxford: Blackwell, 2001, pp 83.1-83.13.

33. Steinberg HO, Chaker H, Leaming R et al. Obesity/ insulin resistance is associated with endothelial dysfunction. Implications for the syndrome of insulin resistance. Journal of Clinical Investigation. 1996; 97: 2601-2610.

34. Al Suwaidi J, Higano ST, Holmes DRJ et al. Obesity is independently associated with coronary endothelial dysfunction in patients with normal or mildly diseased coronary arteries. Journal of the American College of Cardiology. 2001; 37: 1523-1528.

35. Balagopal P, George D, Patton N, Yarandi H, Roberts WL, et al. (2005) Lifestyle-only intervention attenuates the inflammatory state associated with obesity: a randomized controlled study in adolescents. J Pediatr. 146: 342-348.

36. Roth CL, Kratz M, Ralston MM, Reinehr T (2011) Changes in adipose-derived inflammatory cytokines andchemokines after successful lifestyle intervention in obese children. Metabolism. 60: 445-452.

37. Roberts CK, Chen AK, Barnard RJ (2007) Effect of a short-term diet and exercise intervention in youth on atherosclerotic risk factors. Atherosclerosis. 191: 98-106.

38. Angelico F, Loffredo L, Pignatelli P, Augelletti T, Carnevale R, Pacella A, Albanese F, Mancini I, Di Santo S, Del Ben M, Violi F. Weight loss is associated with improved endothelial dysfunction via NOX2-generated oxidative stress downregulation in patients with the metabolic syndrome. Intern Emerg Med. 2012; 7: 219-227. PubMed. 39. Bacchi E, Negri C, Targher G, Faccioli N, Lanza M, Zoppini $G$, et al: Both resistance training and aerobic training reduce hepatic fat content in type 2 diabetic subjects with nonalcoholic fatty liver disease (the RAED2 randomized trial). Hepatology. 2013; 58: 1287-1295. PubMed.

40. Ahmadizad S, Haghighi AH, Hamedinia MR. Effects of resistance versus endurance training on serum adiponectin and insulin resistance index. European Journal of Endocrinology. 157: 625-631, 2007.

41. Keogh JB, Brinkworth GD, Noakes M, Belobrajdic DP, Buckley JD, Clifton PM. Effects of weight loss from a very-low-carbohydrate diet on endothelial function and markers of cardiovascular disease risk in subjects with 
abdominal obesity. Am J Clin Nutr. 2008; 87:567-576. PubMed.

42. Hamdy O, Ledbury S, Mullooly C, Jarema C, Porter S, Ovalle K, Moussa A, Caselli A, Caballero AE, Economides PA et al. Lifestyle modification improves endothelial function in obese subjects with the insulin resistance syndrome. Diabetes Care. 2003; 26:2119-2125. PubMed. 43. Wegge JK, Roberts CK, Ngo TH, Barnard RJ. Effect of diet and exercise intervention on inflammatory and adhesion molecules in postmenopausal women on hormone replacement therapy and at risk for coronary artery disease. Metabolism. 2004; 53:377-381. PubMed.

44. Rector RS, Turk JR, Sun GY, Guilford BL, Toedebusch BW, McClanahan MW, Thomas TR. Short-term lifestyle modification alters circulating biomarkers of endothelial health in sedentary, overweight adults. Appl Physiol Nutr Metab. 2006; 31:512-517.

45. Sharman MJ, Volek JS: Weight loss leads to reductions in inflammatory biomarkers after a very-low-carbohydrate diet and a low-fat diet in overweight men. Clin Sci (Lond) 2004, 107:365-369. PubMed.

46. Forsythe CE, Phinney SD, Fernandez ML, Quann EE, Wood RJ, Bibus DM, Kraemer WJ, Feinman RD, Volek JS: Comparison of low fat and low carbohydrate diets on circulating fatty acid composition and markers of inflammation. Lipids 2008, 43:65-77. PubMed.

47. Thomson RL, Brinkworth GD, Noakes M, Clifton PM, Norman RJ, Buckley JD. The effect of diet and exercise on markers of endothelial function in overweight and obese women with polycystic ovary syndrome. Hum Reprod. 2012 Jul; 27(7):2169-76.

48. Garanty-Bogacka B, Rać M, Syrenicz M, Gębala A, Walczak M, Syrenicz A. Changes in Serum Adipocytokines and Inflammatory Biomarkers Following One-Year of Exercise Training in Obese Adolescents . J Diabetes Metab. 2012, 3:7: 212-217. PubMed.

49. Nijhuis J, van Dielen FM, Fouraschen SM, van den Broek MA, Rensen SS, Buurman WA, Greve JW. Endothelial activation markers and their key regulators after restrictive bariatric surgery. Obesity (Silver Spring). 2007; 15:1395-1399.

50. Uzun H, Zengin K, Taskin M, Aydin S, Simsek G, Dariyerli N. Changes in leptin, plasminogen activator factor and oxidative stress in morbidly obese patients following open and laparoscopic swedish adjustable gastric banding. Obes Surg. 2004; 14:659-665. PubMed.

51. Walther C, Gielen S, Hambrecht R. The effect of ex- ercise training on endothelial function in cardiovascular disease in humans. Exerc Sport Sci Rev. 2004; 32:129-134. PubMed.

52. Schjerve IE, Tyldum GA, Tjonna AE, Stolen T, Loennechen JP, Hansen HE, Haram PM, Heinrich G, Bye A, Najjar SM et al. Both aerobic endurance and strength training programmes improve cardiovascular health in obese adults. Clin Sci (Lond) 2008; 115:283-293. PubMed. 53. Lang HF, Chou CY, Sheu WH, Lin JY. Weight loss increased serum adiponectin but decreased lipid levels in obese subjects whose body mass index was lower than 30 $\mathrm{kg} / \mathrm{m}^{2}$. Nutr Res. 2011 May; 31(5):378-86.

54. Esposito K, Pontillo A, Di Palo C, Giugliano G, Masella M, Marfella R, et al. Effect of weight loss and lifestyle changes on vascular inflammatory markers in obese women: a randomized trial. JAMA. 2003; 289:1799-804 PubMed.

55. Ryan AS, Nicklas BJ, Berman DM, Elahi D. Adiponectin levels do not change with moderate dietary induced weight loss and exercise in obese postmenopausal women. Int J Obes Relat Metab Disord. 2003; 27:1066-71.

56. Rokling-Andersen MH, Reseland JE, Veierød MB, Anderssen SA, Jacobs DR Jr, Urdal P, Jansson JO, Drevon CA. Effects of long-term exercise and diet intervention on plasma adipokine concentrations. Am J Clin Nutr. 2007 Nov; 86(5):1293-301.

57. Habib P, Scrocco JD, Terek M, Vanek V, Mikolich JR. Effects of bariatric surgery on inflammatory, functional and structural markers of coronary atherosclerosis. $A m \mathrm{~J}$ Cardiol. 2009; 104:1251-1255. PubMed.

58. Sledzinski T, Sledzinski M, Smolenski RT, Swierczynski J. Increased serum nitric oxide concentration after bariatric surgery--a potential mechanism for cardiovascular benefit. Obes Surg. 2010; 20:204-210. PubMed.

59. Moschen AR, Molnar C, Geiger S, Graziadei I, Ebenbichler CF, Weiss H, Kaser S, Kaser A, Tilg H. Anti-inflammatory effects of excessive weight loss: Potent suppression of adipose interleukin 6 and tumour necrosis factor alpha expression. Gut. 2010; 59:1259-1264. PubMed.

60.Laimer M, Ebenbichler CF, Kaser S, Sandhofer A, Weiss H, Nehoda H, Aigner F, Patsch JR. Markers of chronic inflammation and obesity: A prospective study on the reversibility of this association in middle-aged women undergoing weight loss by surgical intervention. Int J Obes Relat Metab Disord. 2002; 26:659-662.

61.Garcia de la Torre N, Rubio MA, Bordiu E, Cabre- 
rizo L, Aparicio E, Hernandez C, Sanchez- Pernaute A, Diez-Valladares L, Torres AJ, Puente M, Charro AL. Effects of weight loss after bariatric surgery for morbid obesity on vascular endothelial growth factor-a, adipocytokines, and insulin. J Clin Endocrinol Metab. 2008; 93:4276-4281.

62. Jung SH, Park HS, Kim KS, Choi WH, Ahn CW, Kim BT, et al., 2008. Effect of weight loss on some serum cytokines in human obesity:increase in IL-10 after weight loss. J Nutr Biochem; 19:371-375.

63. Jones TE, Basilio JL, Brophy PM, McCammon MR, Hicknern RC, 2009. Long-term Exercise Training in Overweight Adolescents Improves Plasma Peptide YY and Resistin. Obesity; 17: 1189-1195.
64. Kadoglou NP, Perrea D, Iliadis F, Angelopoulou N, Liapis C, Alevizos M, 2007. Exercise Reduces Resistin and Inflammatory Cytokines in Patients With Type 2 Diabetes. Diabetes Care; 30:719-721.

65. Elloumi M, Ben-Ounis O, Makni E, Van Praagh E, Tabka Z, Lac G, 2009. Effect of individualized weightloss programmes on adiponectin, leptin and resistin levels in obese adolescent boys. Acta Padiatrica; 98: 1487-1493. 66. Balducci S, Zanuso S, Nicolucci A, Fernando F, Cavallo S, Cardelli P, et al., 2010. Anti-inflammatory effect of exercise training in subjects with type 2 diabetes and the metabolic syndrome is dependent on exercise modalities and independent of weight loss. Nutr Metab Cardiovasc Dis; 20: 608-617. 